\title{
Genetic variation of maiden lily (Lilium rubellum Baker) within and among three natural populations in Fukushima Prefecture in Japan
}

\author{
Variación Genética del Lirio Rosa (Lilium rubellum Baker) dentro y entre tres poblaciones naturales \\ de la Prefectura de Fukushima en Japón
}

\author{
Castro, M. $\left({ }^{1}\right)^{*}$; Nishikawa, T.( $\left.{ }^{2}\right)$
}

*Corresponding author: rcastro@lamolina.edu.pe

\begin{abstract}
Lily (genus Lilium) is one of the most important flowers for bulb and cut flower production in the world. Lilium rubellum Baker is a native species of Japan that exhibits early flowering, is pink coloured, and possesses a pleasant fragrance, which makes it an important genetic resource for breeding lilies. In this work, the genetic diversity of L. rubellum was studied among three natural populations located in Fukushima Prefecture, Japan, which have been designated as the Mt. Azuma, Nango and Atsushio-kano populations. A total of 31 accessions collected in 1997 were analysed using Random Amplified Polymorphic DNA (RAPD) markers. Eighteen decamer primers produced $98 \%$ polymorphic RAPD bands; furthermore, 11 of the 18 primers produced 10 or more polymorphic bands with a mean per primer Polymorphic Information Content of 0.382 . Among the three populations, the mean Shannon index, Nei's gene diversity and percentage of polymorphic loci were $0.2749,0.4099$ and $76.7 \%$, respectively. These data revealed that there is a high genetic diversity within all the populations. Analysis of the three genetic diversity indices within populations showed that the Nango population had the highest genetic diversity, whereas the Atsushio-kano population had the lowest. An unweighted pair group method with arithmetic mean dendrogram based on Jaccard's similarity coefficient was constructed, and the three populations of L. rubellum collected in the Fukushima prefecture were clearly differentiated at 0.61 similarity index. The Nango and Mt. Azuma populations were genetically closer than the Atsushio-kano population. The analysis of molecular variance showed a $29.53 \%$ variance among the populations. This study revealed that there is high genetic diversity within populations and moderate genetic diversity among the three natural populations of L. rubellum Baker in the Fukushima Prefecture of Japan.
\end{abstract}

Keywords: genetic diversity, RAPD marker, Lilium rubellum

\section{Resumen}

El Lirio (género Lilium) es una de las flores bulbosas de corte más importantes en el mundo. Lilium rubellum Baker es una especie nativa de Japón, produce una floración muy temprana de color rosado, y una agradable fragancia, por lo que esta especie es un importante recurso genético para el mejoramiento genético de los lirios. En este trabajo se estudió la diversidad genética de L. rubellum entre tres poblaciones naturales de la prefectura de Fukushima en Japón: Mt. Azuma, Nango y Atsushio-Kano. Se analizaron un total de 31 accesiones mediante la prueba de ADN polimórfico amplificado aleatorio (RAPD). 18 decámeros cebadores produjeron $98 \%$ de bandas polimórficas, 11 de estos 18 cebadores producen 10 o más bandas polimórficas con una media por cebador de Contenido de Información Polimórfica (PIC) $=0.382$. La media del índice de Sahnnon Ho $=0.2749$, de la diversidad genética de Nei He $=0.4099$ y el porcentaje de loci Polimórficos $=76.7$ revelaron que existe una alta diversidad genética dentro de todas estas poblaciones. Los análisis de los tres índices de diversidad genética intrapoblacional, mostraron que la población de Nango tenía la mayor diversidad genética y la población de Atsushio-kano la más baja. Se construyó un dendrograma UPGMA basado en el coeficiente de similitud de Jaccard y con un índice de similitud de 0.61 , las tres poblaciones de L. rubellum recolectadas en la prefectura de Fukushima fueron claramente diferenciadas. Las poblaciones de Nango y de Monte Azuma estaban más cercanamente relacionadas genéticamente que con la población de Atsushio-kano. Con el análisis de la varianza molecular (AMOVA) se observó que existe un $29,53 \%$ variación interpoblacional. Este estudio reveló que existe una alta diversidad genética dentro de las poblaciones y una moderada diversidad genética entre las tres poblaciones naturales de L. rubellum Baker en la prefectura de Fukushima en Japón.

\section{Palabras clave: Diversidad genética, marcador RAPD, Lilium rubellum}

\footnotetext{
1 Universidad Nacional Agraria La Molina (UNALM). Jardín Botánico “Octavio Velarde Núñez”. Departamento Académico de Biología. Av. La Molina s/n, Lima 12, Perú. Apartado postal: 12-056, Perú. e-mail: rcastro@lamolina.edu.pe

${ }^{2}$ Genebank National Institute of Agrobiological Sciences 2-1-2 Kannondai, Ibaraki, 305-8602, Japan. e-mail: tomotaro@affrc.go.jp
} 


\section{Introduction}

Ornamental plants are used by humans because of their beauty, symbolic significance (Mendonca de Carvalho, 2011), colour (Kaufman \& Lohr, 2008), fragrance and therapeutic (Matsuo, Takaesu, \& Asano, 2008) and emotional value. The lily has become one of the most important ornamental plants grown for its flower bulbs and cut flowers worldwide over the last 50 years (Van Tuyl \& Arens, 2011). Furthermore, Lilium species can have pharmaceutical applications since they contain steroidal saponins, glycoalkaloids and phenolic glycerides as well as antioxidants (Mammadov, Deniz, Rakhimzhanova, Kilınçarslan, \& Mammadov, 2017).

The centre of origin of the Lilium genus is the Himalayan region in Asia (De Jong, 1974). This genus has about 100 species grouped into seven sections distributed across the Northern hemisphere extending as far south as the Southern Asia (Van Tuyl et al., 2011). Japan is known to be rich in Lilium species. Fifteen species are distributed across all prefectures of Japan, and Japanese Lilium species have played an important role in the development of major important cultivars of Eastern Lily, Asiatic Hybrids and Oriental Hybrids (Okasaki, Asano, \& Oosawa, 1994). However, Lilium species are also under threat of genetic erosion, requiring increased attention and efforts to conserve Lilium germplasm (Yi, Lee, Chung, Lee, \& Lim, 2013).

Lilium rubellum Baker grows wild in the mountainous region of Northeastern Honshu, Japan (McRae, 1998; Shimizu, 1971). It flowers early and has an attractive pink colour and pleasant fragrance (Lim \& Van Tuyl, 2007). It is easily propagated by seed and is cultivated in the Fukushima Prefecture (Okasaki et al., 1994). The desirable quality of this delicate, pink-coloured lily is that it can hybridise with other lilies of the section Archelirion, and their offspring are referred to as Oriental Hybrids, one of the popular variety groups of lilies (Okasaki et al., 1994). Understandably, L. rubellum is an important germplasm resource for breeding lilies, and evaluating its genetic diversity will provide valuable understanding of distinct populations.

Only seven Lilium species have had their genetic diversity assessed using molecular techniques (ArzateFernández, Miwa, Shimada, Yonekura, \& Ogawa, 2005; Huang et al., 2009; Ikinci \& Oberprieler, 2010; Persson, Lundquist, \& Nybom, 1998; Wen \& Hsiao, 2001; Wu et al., 2015). One of the first techniques used in order to assess genetic diversity was Random Amplified Polymorphic DNA (RAPD) markers (Williams, Kubelik, Livak, Rafalski, \& Tingey, 1990). This technique is based on the amplification of discrete DNA segments by polymerase chain reaction (PCR) using small size oligonucleotide primers of random design (Halward, Stalker, LaRue, \& Kochert, 1992; Sharma, Dawson, \& Waugh, 1995)
Currently, there are many other, more modern molecular techniques, but RAPD markers are still useful in large-scale genetic studies of diverse populations (VelascoRamírez, Torres-Morán, Molina-Moret, De Jesús SánchezGonzález, \& Santacruz-Ruvalcaba, 2014). Despite its low resolving power, the simplicity and low cost of agarose gel electrophoresis has made the use of RAPD markers prevalent. The markers are quick, easily generated by PCR, and do not require prior sequence information (Idrees \& Irshad, 2015). Furthermore, their effectiveness in Lilium was established by Yamagishi (1995), who developed RAPD markers for 13 species. In this study, RAPD markers were used (i) to assess the genetic differentiation among populations of L. rubellum in the prefecture of Fukushima, Japan, and (ii) to estimate the levels of genetic diversity within L. rubellum populations. This information will be useful in planning conservation and breeding programmes of L. rubellum

\section{Materials and Methods}

\section{Plant materials}

Leaf samples of 31 individuals of L. rubellum were collected from three different sites in Fukushima Prefecture (Figure 1) located in the north central region of Honshu Island, Japan: 1) Mt. Azuma-Kofuji, Fukushima City (altitude 1,300 MASL; Figure 2); 2) Atsushio-kano Village (currently Kitakata City; altitude, 500 MASL; Figure 3); and 3) Nango Village, figure 4, which consisted of Aburakubo (altitude, 700 MASL), Shimoyama (altitude, 600 MASL), Misawa (altitude, 600 MASL) and Nagachisawaguchi (currently Minamiaizu Town; altitude, 700 MASL). The collections were made in June and July of 1997 (Table 1). The leaves were stored at $-80{ }^{\circ} \mathrm{C}$ until DNA extraction.

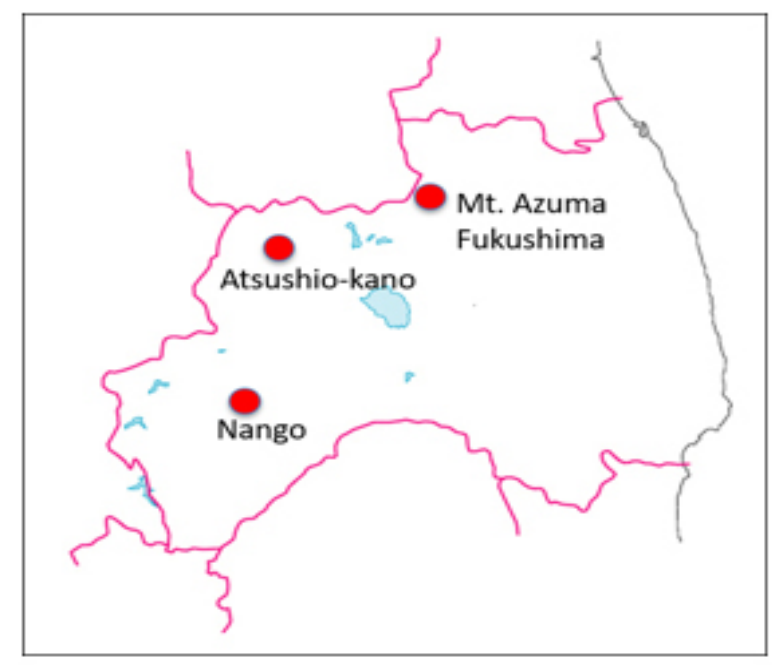

Figure 1. Collection Cities in Fuskushima Prefecture 


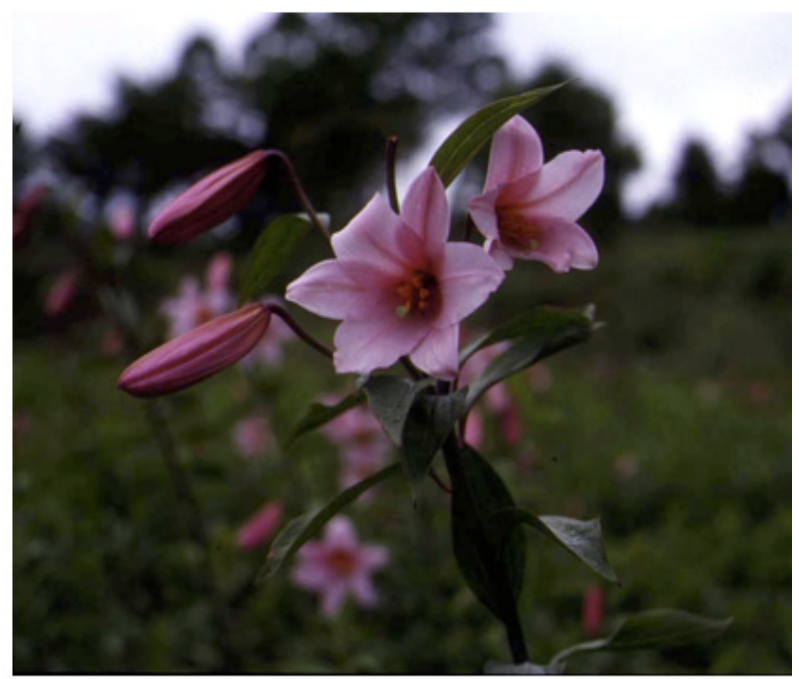

Figure 2. Rose Lily in Mt. Azuma

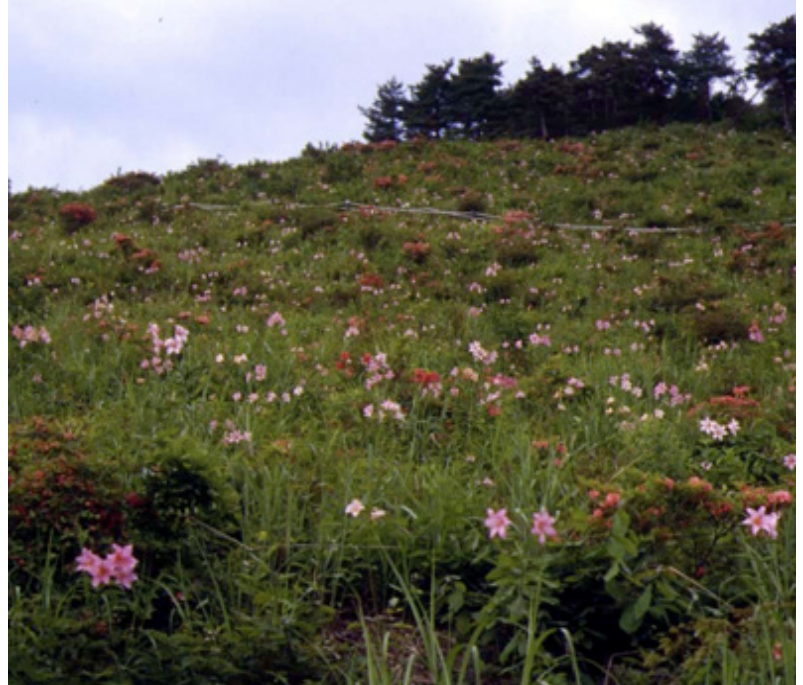

Figure 3. Rose Lily in Atsushio-kano

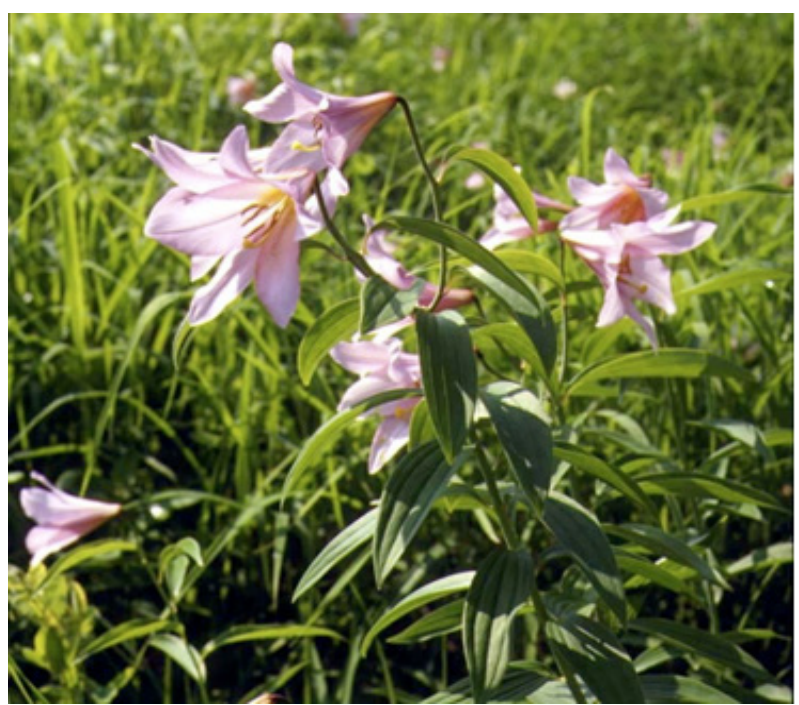

Figure 4. Rose Lily in Nango

\section{DNA extraction}

Total DNA was extracted by the CTAB method (Murray \& Thompson, 1980). Approximately $1 \mathrm{~g}$ of frozen leaves was
Table 1. Sample Name Collected in Fukushima Prefecture

\begin{tabular}{|c|c|c|}
\hline Population & $\begin{array}{l}\text { Accesion } \\
\text { Number }\end{array}$ & Sample Name \\
\hline \multirow{15}{*}{ 1. Mt Azuma } & 1 & Azuma A 8 \\
\hline & 2 & Azuma A 16 \\
\hline & 3 & Azuma B 14 \\
\hline & 4 & Azuma B 11 \\
\hline & 5 & Azuma B 5 \\
\hline & 6 & Azuma A 18 \\
\hline & 7 & Azuma C 13 \\
\hline & 8 & Azuma C 17 \\
\hline & 9 & Azuma C11 \\
\hline & 17 & Azuma A 7 \\
\hline & 18 & Azuma A 6 \\
\hline & 19 & Azuma B 4 \\
\hline & 20 & Azuma B 20 \\
\hline & 21 & Azuma C 16 \\
\hline & 22 & Azuma C 19 \\
\hline \multirow{5}{*}{$\begin{array}{l}\text { 2. Atsushio- } \\
\text { kano }\end{array}$} & 27 & Atsushio-kano Village1 \\
\hline & 28 & Atsushio-kano Village 3 \\
\hline & 29 & Atsushio-kano Village 6 \\
\hline & 30 & Atsushio-kano Village 10 \\
\hline & 31 & Atsushio-kano Village 12 \\
\hline \multirow{11}{*}{ 3. Nango } & 10 & Nango Misawa 5 \\
\hline & 11 & Nango Misawa 1 \\
\hline & 12 & Nango Nagachisawaguchi 2 \\
\hline & 13 & Nango Nagachisawaguchi 13 \\
\hline & 14 & Nango Aburakubo B1 \\
\hline & 15 & Nango Aburakubo 18 \\
\hline & 16 & Nango Shimoyama 1 \\
\hline & 23 & Nango Misawa 6 \\
\hline & 24 & Nango Nagachisawaguchi 18 \\
\hline & 25 & Nango Aburakubo 9 \\
\hline & 26 & Nango Aburakubo B8 \\
\hline
\end{tabular}

ground to a fine powder with liquid nitrogen in a mortar with a pestle. The powder was transferred to a beaker containing $5 \mathrm{~mL}$ of $2 \times$ CTAB buffer $(2 \%$ CTAB, 100 $\mathrm{mM}$ Tris-HCL [pH 8.0], $20 \mathrm{mM}$ EDTA and $1.4 \mathrm{M} \mathrm{NaCl}$ ) and immediately mixed. The mixture was transferred to a centrifuge tube and incubated for $10 \mathrm{~min}$ at $65^{\circ} \mathrm{C}$. An equal volume of chloroform/isoamyl alcohol (24:1) was added and mixed gently for $30 \mathrm{~min}$ at room temperature. Five millilitres of $1 \times$ CTAB buffer $(1 \%$ CTAB, $50 \mathrm{mM}$ Tris- $\mathrm{HCl}$ [pH 8.0], $10 \mathrm{mM}$ EDTA and $0.7 \mathrm{M} \mathrm{NaCl})$ was added to the mixture. After centrifugation at 4,000 rpm for $15 \mathrm{~min}$, the supernatant was transferred to a new tube by decanting. An equal volume of chloroform/isoamyl alcohol (24:1) was added and mixed gently for $10 \mathrm{~min}$, then centrifuge again at 4,000 rpm for $15 \mathrm{~min}$. The supernatant 
was transferred to a new tube and 0.1 vol of $10 \%$ CTAB $(10 \% \mathrm{CTAB}$ and $0.7 \mathrm{M} \mathrm{NaCl})$ was added to obtain a CTAB-nucleic acid precipitate. After gentle inversion, the mixture was left for $30 \mathrm{~min}$ at room temperature. The precipitate was recovered by centrifuging at $4,000 \mathrm{rpm}$ for $15 \mathrm{~min}$ and removing the supernatant. The precipitate was dissolved in $5 \mathrm{~mL}$ of HS-TE $(10 \mathrm{mM}$ Tris- $\mathrm{HCl}[\mathrm{pH}$ 8.0], $1 \mathrm{mM}$ EDTA and $1 \mathrm{M} \mathrm{NaCl}$ ) containing $5 \mu \mathrm{L}$ of RNase and incubated at $55^{\circ} \mathrm{C}$ until completely dissolved. Five millilitres of isopropanol was added to the solution to remove the CTAB. After gentle inversion, the solution was centrifuge at 4,000 rpm for $10 \mathrm{~min}$ and the supernatant was removed. The precipitate was washed with $5 \mathrm{~mL}$ of $70 \%$ ethanol and dissolved in $3 \mathrm{~mL}$ of TE $(10 \mathrm{mM}$ Tris$\mathrm{HCl}$ [pH 8.0] and $1 \mathrm{mM}$ EDTA).

\section{Amplification by $R A P D$ procedures}

A total of 31 accessions from three natural populations of this prefecture were analysed using 18 random decamer primers. For DNA amplification, $10 \mu \mathrm{L}$ of the reaction mixture was prepared, containing $10 \mathrm{ng}$ of DNA, $1 \mu \mathrm{L}$ PCR $10 \times$ buffer $(100 \mathrm{mM}$ Tris- $\mathrm{HCl}$ [pH 8.3], $500 \mathrm{mM}$ $\mathrm{KCl}), 1 \mu \mathrm{L}$ of dNTPs (2.0 mM each), $1.2 \mu \mathrm{L}$ of $\mathrm{MgCl}_{2}$ $(25 \mathrm{mM}), 0.5$ units of DNA polymerase (AmpliTaq Gold), $0.1 \mu \mathrm{L}$ of a decamer primer $(20 \mathrm{pmol} / \mu \mathrm{L})$ and sterilised, distilled water to a final volume of $10 \mu \mathrm{L}$. Amplification was performed in a PTC-100 Programmable Thermal Controller (MJ Research, Inc.) as follows: first cycle at 95 ${ }^{\circ} \mathrm{C}$ for $10 \mathrm{~min}$; followed by 50 cycles at $94{ }^{\circ} \mathrm{C}$ for $1 \mathrm{~min}$, $35^{\circ} \mathrm{C}$ for $1 \mathrm{~min}$ and at $72{ }^{\circ} \mathrm{C}$ for $2 \mathrm{~min}$; and 1 cycle at 94 ${ }^{\circ} \mathrm{C}$ for $1 \mathrm{~min} ; 35^{\circ} \mathrm{C}$ for $1 \mathrm{~min}$ at $72^{\circ} \mathrm{C}$ for $5 \mathrm{~min}$; and a final hold at $4{ }^{\circ} \mathrm{C}$. For each RAPD assay, primers of the PC, $\mathrm{RA}, \mathrm{OPA}, \mathrm{OPB}$ and OPC series were randomly selected (Table 2). The amplified DNA segments were separated in $1.5 \%$ agarose gels $(20 \times 15 \mathrm{~cm})$ prepared in TBE buffer (Sambrook, Fritsch, \& Maniatis, 1989). Electrophoresis was performed at $80 \mathrm{~V}$ for $4 \mathrm{~h}$. Then the gel was stained with ethidium bromide $(0.5 \mu \mathrm{g} / \mathrm{mL})$ and the bands were visualised using ultraviolet light.

\section{Data analysis}

Scoring of polymorphic DNA fragments was done using 1 or 0 representing the presence or absence of a polymorphic band, respectively. From these data, the Polymorphic Information Content (PIC) per primer and the genetic similarity between genotypes of the three sampled populations were estimated using the Jaccard similarity coefficient, which was calculated using NTSYS-pc software version 2.2 (Rohlf, 1992; Van Tuyl \& Arens, 2011; Van Tuyl et al., 2011). Based on the resulting similarity matrix, a grouping analysis was performed with the unweighted pair-group method using arithmetic averages (UPGMA). For assessing genetic variation within populations, the programme GenAlEx 6.5 (Peakall \& Smouse, 2012) was used. Nei's gene diversity $(1973)\left(H_{\mathrm{e}}\right)$ and Shannon index $\left(H_{\mathrm{o}}\right)$ were also estimated. Analyses of molecular variance (AMOVA) between and within populations were calculated using the ARLEQUIN software version 3.5 (Excoffier \& Lischer, 2010)

Table 2. Primers and Polymorphic Information Content

\begin{tabular}{|c|c|c|c|c|c|}
\hline Primer Code & Sequence & $\begin{array}{c}\text { Number of Amplified } \\
\text { Bands }\end{array}$ & $\begin{array}{c}\text { Number of } \\
\text { Polymorphic Bands }\end{array}$ & $\% \mathrm{GC}$ & PIC \\
\hline OPA-08 & 5'-GTGACGTAGG-3' & 13 & 13 & 60 & 0.344 \\
\hline OPA-09 & 5'-GGGTAACGCC-3' & 14 & 13 & 70 & 0.414 \\
\hline OPA-10 & 5'-GTGATCGCAG-3' & 9 & 9 & 60 & 0.413 \\
\hline OPB-01 & 5'- GTTTCGCTCC-3' & 14 & 14 & 60 & 0.457 \\
\hline OPB-08 & 5'-GTCCACACGG-3' & 11 & 11 & 70 & 0.380 \\
\hline OPB-17 & $5^{\prime}$-AGGGAACGAG-3' & 14 & 12 & 60 & 0.283 \\
\hline OPC-01 & 5'-TTCGAGCCAG-3' & 9 & 8 & 60 & 0.377 \\
\hline OPC-08 & 5'-TGGACCGGTG-3' & 12 & 12 & 70 & 0.364 \\
\hline OPC-09 & 5'-CTCACCGTCC-3' & 8 & 8 & 70 & 0.391 \\
\hline OPC-15 & $5^{\prime}$-GACGGATCAG-3' & 7 & 7 & 60 & 0.358 \\
\hline OPC-04 & 5'-CCGCATCTAC-3' & 16 & 16 & 60 & 0.428 \\
\hline Pc 3 & 5'-AACCGCGCTC-3' & 14 & 14 & 70 & 0.382 \\
\hline Pc 7 & 5'-CGCGGACGAT-3' & 11 & 11 & 70 & 0.432 \\
\hline RA 3 & 5'-CGATCGAGGA-3' & 9 & 9 & 60 & 0.431 \\
\hline RA5 & $5^{\prime}$-AAGCAGCAAG-3' & 10 & 10 & 50 & 0.341 \\
\hline RA35 & 5'-AAGCTCCCCG-3' & 9 & 9 & 70 & 0.456 \\
\hline RA37 & 5'-TGTGGCCGGT-3' & 11 & 11 & 70 & 0.378 \\
\hline RA41 & 5'-GAGTGCGCAG-3' & 9 & 9 & 70 & 0.317 \\
\hline \multicolumn{2}{|c|}{ Total Number of Bands } & 200 & 196 & & \\
\hline
\end{tabular}




\section{Results}

\section{Degree of polymorphism}

A total of 200 bands were amplified using 18 primers, and 196 were polymorphic ( $98 \%$; Table 2$)$. They ranged in size from 0.20 to $2.24 \mathrm{~kb}$. The number of bands per primer varied from 7 to 16 with a mean of 11.1. In this study, $100 \%$ of the primers used produced polymorphic bands.

Table 3. Genetic diversity indices of three populations of Lilium rubellum

\begin{tabular}{cccc}
\hline Populations & $H \mathrm{e}$ & $\mathrm{Ho}$ & $\begin{array}{c}\% \\
\text { polymorphic } \\
\text { loci }\end{array}$ \\
\hline $\begin{array}{c}\text { Mt. Azuma } \\
\text { Atsushio- } \\
\text { kano }\end{array}$ & 0.284103443 & 0.421575859 & 78.5 \\
Nango & 0.24402529 & 0.365970296 & 68.5 \\
Mean & 0.296599687 & 0.442330341 & 83 \\
\hline
\end{tabular}

$\mathrm{He}$, genetic diversity of Nei; Ho, Shannon index.

Table 4. Summary of analysis of molecular variance for the three populations of Lilium rubellum

\begin{tabular}{cccc}
\hline Source of Variation & $\begin{array}{c}\text { Sum of } \\
\text { squares }\end{array}$ & $\begin{array}{c}\text { Variance } \\
\text { Components }\end{array}$ & $\begin{array}{c}\text { Percentage } \\
\text { Variation }\end{array}$ \\
\hline Among populations & 314.52 & 13.21 & 29.52 \\
Within populations & 883.03 & 31.54 & 70.46 \\
Total & 1197.55 & 44.75 & \\
\hline
\end{tabular}

Fst $=0.2952$

\section{Genetic diversity}

In this study, the Nei's gene diversity or expected heterozygosity $H_{\mathrm{e}}$ within populations ranged from 0.244 (Atsushio-kano population) to 0.296 (Nango population) as shown in Table 3. The Shannon index $H$ ranged from 0.365 (Atsushio-kano population) to 0.442 (Nango population). It is important to note that the Shannon index ranges from 0 to 1 , and the closer the value is to one, the higher the diversity. The percentage of polymorphic loci ranged from $68.5 \%$ (Atsushio-kano population) to $83 \%$ (Nango population). The Nei's gene diversity $H_{e}$, the Shannon index $H_{o}$, and the percentage of polymorphic loci were $0.275,0.409$ and $76.7 \%$, respectively; this showed a relatively high genetic diversity within the populations of L. rubellum.

\section{Genetic structure}

The similarity matrix calculated using the Jaccard coefficient between genotypes based on RAPD markers exhibited coefficients of similarity between pairs of genotypes that ranged from 0.54 to 0.85 (Figure 5). The greatest similarity was found between the individuals from C 13 and C 17 from Mt. Azuma (0.85). In the dendrogram at 0.61 similarity index, the three populations of L. rubellum collected in Fukushima Prefecture were clearly differentiated. Population 1, made up of 15 samples taken in Mt. Azuma-Fukushima City, had a percentage of similarity with a range of $0.66 \%-0.85 \%$; Population 2 , made up of five samples taken in Atsushio-kano Village, had a percentage of similarity with a range of $0.62 \%-$ $0.74 \%$; and Population 3, made up of 11 samples taken in

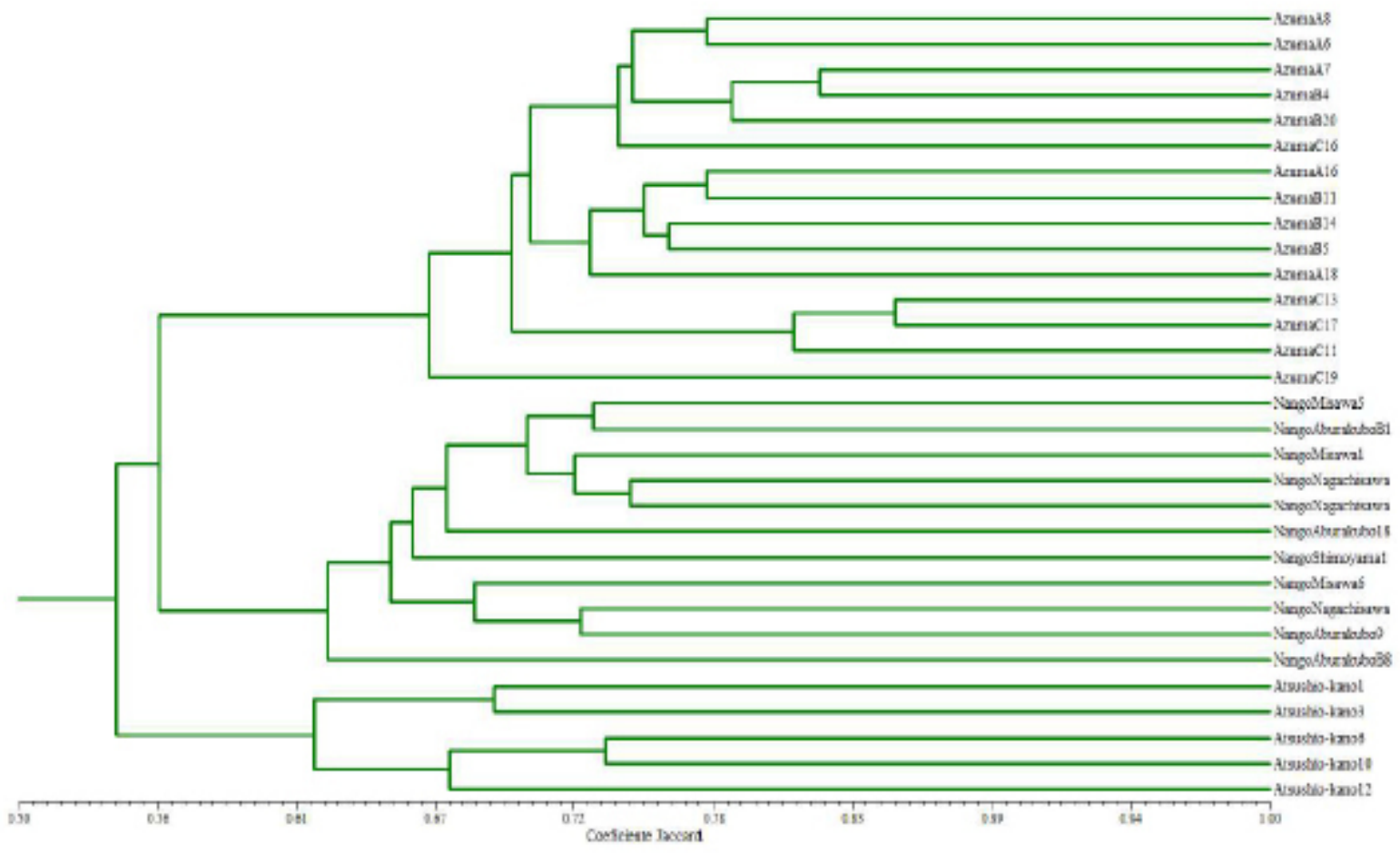

Figure 5. UPGMA dendrogram based on JaccardÆs similarity coefficients 
the Nango villages, had a percentage of similarity with a range of $0.63 \%-0.76 \%$ (Table 1; Figure 5). The Nango and Mt. Azuma populations were closer genetically than the Atsushio-kano population. As shown in Table 4, AMOVA analysis revealed that of the total variation, $29.52 \%$ occurred among the populations and the remainder within the populations.

\section{Discussion}

Three natural populations of L. rubellum in Fukushima Prefecture, Japan, were analysed by RAPD marker analysis with 18 primers to produce bands, $98 \%$ of which were polymorphic. Eleven of these primers showed $\geq 10$ polymorphic bands (OPA-08, OPA-09, OPB-01, OPB-08, OPB-17, OPC-08, OPC-04, Pc 3, Pc 7, RA5 and RA37) with a PIC mean of $76.7 \%$. In future analyses, primers that produce $\geq 10$ polymorphic bands would be useful in evaluating the genetic variability in L. rubellum.

The genetic diversity mean of L. rubellum $\left(H_{\mathrm{o}}=0.2749\right.$, $H_{\mathrm{e}}=0.4099$, and percentage of polymorphic loci $=76.7 \%$ ) compared with other narrowly distributed species of the genus Lilium, was moderately high (Guo et al., 2011) and very similar to the genetic diversity of $L$. regale $\left(H_{\mathrm{o}}=\right.$ 0.2750). Of the three populations analysed, the Nango population showed the highest genetic diversity and the Atsushio-kano population showed the lowest genetic diversity within the respective populations. The Mt. Azuma population had intermediate values of the three indices analysed. Since these samples were collected near the alpine belt (approximately 1,300 MASL), the population was expected to have greater variation because subalpine species have been shown to harbour greater variation in the highlands of central Japan (Ohsawa \& Ide, 2011). The relatively high genetic diversity of $L$. rubellum may be attributable to its potential mixed mating system and longrange pollen and seed dispersal, which is also common in other Lilium species like $L$. regale (Wu et al., 2015)

In the UPGMA dendrogram at 0.61 similarity index, the three populations of L. rubellum collected in Fukushima Prefecture were clearly differentiated. The analysis of interpopulation variation through AMOVA showed that there was $29.52 \%$ of variation among populations. Moreover, Nango is located at the southern edge of the distribution of L. rubellum, and it is closer geographically to the Atsushio-kano Village (outside Kitakata Town) than to Mt. Azuma, Fukushima City (Figure 1). Despite geographic distances, as can be seen in the dendrogram (Figure 5), the populations of Mt. Azuma and Nango were in the same cluster $(0.55)$, indicating that they are closely related compared to the Atsushio-kano population. However, the number of samples collected representing the Atsushio-kano population was quite small. In future analysis, a higher number of samples collected in this village should be taken in order to validate the accuracy of population clustering.

\section{Conclusions}

The assessment of genetic diversity is of great importance to the sustainability of plant populations (Wang et al., 2007). The evolutionary potential of a species largely depends on its level of genetic variability, and, for plants, the overall level of genetic variability in a population is often correlated with the geographical distribution range of the species (Hamrick \& Godt, 1996). The wide separation between populations found based on results of the AMOVA analysis may result in increased genetic diversity due to the fact that there may be little cross pollination among the three populations included in this study. The populations sampled in this study were separated by many kilometres, and distance could be a significant factor accounting for the relatively high genetic variation among populations.

We hope that the genetic diversity evaluated in germplasm collected over 20 years ago will serve to compare with the genetic diversity that can be found using other molecular markers. The L. rubellum populations reported here offer important information on the conservation strategies for this endangered species and may be of value to breeding programmes.

\section{Acknowledgements}

We would like to thank the Japan International Cooperation Agency (JICA) for their financial support, Dr. T. Nagamine for facilities usage, and Ms. N. Nakamaru for her technical assistance. We also would like to acknowledge Mr. Y. Ohno, Mr. Y. Meguro and Mr. M. Sugano for their supply of materials and cooperation in collecting materials.

\section{References}

Arzate-Fernández, A. M., Miwa, M., Shimada, T., Yonekura, T., \& Ogawa, K. (2005). Genetic diversity of Miyamasukashi-yuri (Lilium maculatum Thunb. var. bukosanense), an endemic and endangered species at Mount Buko, Saitama, Japan. Plant Species Biology, 20(1), 57-65. https:// doi.org/10.1111/j.1442-1984.2005.00124.x

De Jong, P. C. (1974). Some notes of Lilium Evolution. Some Notes of Lilium Evolution., pp. 23-28. The Lily Yearbook of the North American Lily Society Evolution.

Excoffier, L., \& Lischer, H. E. L. (2010). Arlequin suite ver 3.5: A new series of programs to perform population genetics analyses under Linux and Windows. Molecular Ecology Resources, 10(3), 564-567. 
https://doi.org/10.1111/j.1755-0998.2010.02847.x

Guo, W., Jeong, J., Kim, Z., Wang, R., Kim, E., \& Kim, S. (2011). Genetic diversity of Lilium tsingtauense in China and Korea revealed by ISSR markers and morphological characters. Biochemical Systematics and Ecology, 39(4-6), 352-360. https://doi. org/10.1016/j.bse.2011.05.002

Halward, T., Stalker, T., LaRue, E., \& Kochert, G. (1992). Use of single-primer DNA amplifications in genetic studies of peanut (Arachis hypogaea L.). Plant Molecular Biology, 18, 315-325

Hamrick, J. L., \& Godt, M. J. W. (1996). Conservation Genetics of Endemic Plant Species. In C. Avise \& J. L. Hamrick (Eds.), Conservation Genetics, Case Histories from Nature (pp. 281-304). London: Chapman \& Hall.

Huang, Y. F., Yang, M. X., Zhang, H., Zhuang, X. Y., Wu, X. H., \& Xie, W. (2009). Genetic Diversity and Genetic Structure Analysis of the Natural Populations of Lilium brownii from Guangdong, China. Biochemical Genetics, 47(7-8), 503-510. https://doi.org/10.1007/s10528-009-9258-y

Idrees, M., \& Irshad, M. (2015). Molecular Markers in Plants for Analysis of Genetic Diversity: A Review. European Academic Research, 2(1), 1513-1540.

Ikinci, N., \& Oberprieler, C. (2010). Genetic relationships among NE Turkish Lilium L. (Liliaceae) species based on a random amplified polymorphic DNA analysis. Plant Systematics and Evolution, 284(1), 41-48. https://doi.org/10.1007/s00606-009-0239-8

Kaufman, A. J., \& Lohr, V. I. (2008). Does it Matter What Color Tree You Plant? Acta Horticulturae, 790, 179-184. https://doi.org/10.17660/ actahortic.2008.790.25

Lim, K., \& Van Tuyl, J. M. (2007). Lily. In N. O. Anderson (Ed.), Flower Breeding and Genetics (pp. 517 537). Dordrecht: Springer

Mammadov, T., Deniz, N., Rakhimzhanova, A., Kılınçarslan, Ö., \& Mammadov, R. (2017). Studies on lilium species. International Journal of Secondary Metabolite, 4(1), 47-60. https://doi. org/10.21448/ijsm.282978

Matsuo, E., Takaesu, Y., \& Asano, F. (2008). History, development and legacy of the $8^{\text {th }}$ International People-Plant Symposium (IPPS 2004 in Awaji). Acta Horticulturae, 790, 21-25. https://doi. org/10.17660/ActaHortic.2008.790.1

McRae, E. A. (1998). Lilies: A Guide for Growers and Collectors. Oregon: Timber Press.

Mendonca de Carvalho, L. M. (2011). The symbolic uses of plants. In N. Anderson, E.N.; Pearsall, D.M.; Hunn, Eugene S.; Turner (Ed.), Ethnobiology (pp. 351-369). New Jersey: Wiley-Blackwell. A John Wiley \& Sons, Inc.

Murray, M. G., \& Thompson, W. F. (1980). Rapid isolation of high molecular weight plant DNA. Nucleic Acids Research, 8(19), 4321-4326.

Nei, M. (1973). Analysis of gene diversity in subdivided populations. Proceedings of the National Academy of Sciences of the United States of America, 70(12), 3321-3323. https://doi.org/10.1073/ pnas. 70.12 .3321

Ohsawa, T., \& Ide, Y. (2011). Phylogeographic patterns of highland and lowland plant species in Japan. Alpine Botany, 121(1), 49-61. https://doi.org/10.1007/ s00035-010-0083-z

Okasaki, K., Asano, Y., \& Oosawa, K. (1994). Interspecific hybrids between Lilium Oriental hybrid and L. Asiatic hybrid produced by embryo culture with revised media. Breeding Science, (44), 59-64. https://doi.org/10.1270/jsbbs1951.44.59

Peakall, R., \& Smouse, P. (2012). GENALEX 6.5: genetic analysis in Excel. Population genetic software for teaching and research- an update. Bioinformatics, 28(19), 2537-2539. https://doi.org/10.1093/ bioinformatics/bts460

Persson, H. A., Lundquist, K., \& Nybom, H. (1998). RAPD analysis of genetic variation within and among populations of Turk's-cap lily (Lilium martagon L.). Hereditas, 128(3), 213-220. https:// doi.org/10.1111/j.1601-5223.1998.00213.x

Rohlf, F. J. (1992). NTSYS-pc: numerical taxonomy and multivariate analysis system. Applied Biostatistics.

Sambrook, J., Fritsch, E. F., \& Maniatis, T. (1989). Molecular cloning: a laboratory manual (No. Ed. 2). (2nd ed.). Cold spring harbor laboratory press.

Sharma, S. K., Dawson, I. K., \& Waugh, R. (1995). Relationships among cultivated and wild lentils revealed by RAPD analysis. Theoretical and Applied Genetics, 91(4), 647-654. https://doi. org/10.1007/BF00223292

Shimizu, M. (1971). Lilies in Japan (In Japanese) Seibundo Shinko-Sha. In Lilies of Japan (In Japanese). Tokyo: Seibundo-Shinkosha Co. Ltd.

Van Tuyl, J. M., \& Arens, P. (2011). Lilium: Breeding history of the modern cultivar assortment. Acta Horticulturae, 900, 223-230. https:/doi. org/10.17660/ActaHortic.2011.900.27

Van Tuyl, J. M., Arens, P., Ramanna, M. S., Shahin, A., Khan, N., Xie, S., Barba-Gonzalez, R. (2011). 
Lilium. In C. Kole (Ed.), Wild Crop Relatives: Genomic and Breeding Resources. Plantation and Ornamental Crops (pp. 161-183). Springer-Verlag Berlin Heidelberg.

Velasco-Ramírez, A. P., Torres-Morán, M. I., MolinaMoret, S., De Jesús Sánchez-González, J., \& Santacruz-Ruvalcaba, F. (2014). Efficiency of RAPD, ISSR, AFLP and ISTR markers for the detection of polymorphisms and genetic relationships in camote de cerro (Dioscorea spp.). Electronic Journal of Biotechnology, 17(2), 65-71. https://doi.org/10.1016/j.ejbt.2014.01.002

Wang, W., Chen, L., Yang, P., Hou, L., He, C., Gu, Z., \& Liu, Z. (2007). Assessing genetic diversity of populations of topmouth culter (Culter alburnus) in China using AFLP markers. Biochemical Systematics and Ecology, 35(10), 662-669. https:// doi.org/10.1016/j.bse.2007.04.008

Wen, C. S., \& Hsiao, J. Y. (2001). Altitudinal Genetic Differentiation and Diversity of Taiwan Lily (Lilium longiflorum var. formosanum; Liliaceae) Using RAPD Markers and Morphological Characters Author (s): C. S. Wen and J. Y. Hsiao Published by: The University of Chicago Press. International Journal of Plant Science, 162(2), 287-295.

Williams, J. G. K., Kubelik, A. R., Livak, K. J., Rafalski, J. A., \& Tingey, S. V. (1990). DNA polymorphisms amplified by arbitrary primers are useful as genetic markers. Nucleic Acids Research, 18(22), 65316535. https://doi.org/10.1093/nar/18.22.6531

Wu, Z. H., Shi, J., Xi, M. L., Jiang, F. X., Deng, M. W., \& Dayanandan, S. (2015). Inter-simple sequence repeat data reveals high genetic diversity in wild populations of the narrowly distributed endemic lilium regale in the Minjiang River valley of China. PLoS ONE, 10(3), 1-17. https://doi.org/10.1371/ journal.pone.0118831

Yamagishi, M. (1995). Detection of section-specific random amplified polymorphic DNA (RAPD) markers in Lilium. Theoretical and Applied Genetics, 91(6-7), 830-835. https://doi.org/10.1007/BF00223888

Yi, J. Y., Lee, G. A., Chung, J. W., Lee, S. Y., \& Lim, K. B. (2013). Efficient cryopreservation of Lilium spp. shoot tips using droplet-vitrification. y, 1(2), Plant Breeding and Biotechnology, 131-136. 